\title{
Lipid Droplet Formation in HeLa Cervical Cancer Cells Depends on Cell Density and the Concentration of Exogenous Unsaturated Fatty Acids
}

\author{
Ema Guštin, ${ }^{1, \#}$ Eva Jarc, ${ }^{1,2, \#}$ Ana Kump ${ }^{1,2}$ and Toni Petan ${ }^{1, *}$ \\ ${ }^{1}$ Department of Molecular and Biomedical Sciences, Jožef Stefan Institute, Ljubljana, Slovenia \\ ${ }^{2}$ Jožef Stefan International Postgraduate School, Ljubljana, Slovenia \\ \# These authors contributed equally to this work. \\ * Corresponding author: E-mail: toni.petan @ijs.si \\ Phone: + 38614773713
}

Received: 12-09-2016

For Cutting Edge 2017

\begin{abstract}
Cytosolic lipid droplets (LDs) store excess fatty acids (FAs) in the form of neutral lipids and prevent starvation-induced cancer cell death. Here we studied the ability of mono- and polyunsaturated FAs to affect LD formation and survival in HeLa cervical cancer cells. We found that the LD content in HeLa cells increases with cell density, but it decreases in MDA-MB-231 breast cancer cells. Exogenously-added unsaturated FAs, including oleic (OA), linoleic (LA), arachidonic (AA), eicosapentaenoic (EPA) and docosahexaenoic acid (DHA) displayed a similar ability to alter LD formation in HeLa cells. There was a dual, concentration-dependent effect on neutral lipid accumulation: low micromolar concentrations of LA, AA and DHA reduced, while all FAs induced LD formation at higher concentrations. In serum starved HeLa cells, OA stimulated LD formation, but, contrary to expectations, it promoted cell death. Our results reveal a link between cell population density and LD formation in HeLa cells and show that unsaturated FAs may both suppress or stimulate LD formation. This dynamic regulation of LD content must be accounted for when studying the effects of lipids and lipid metabolism-targeting drugs on LD metabolism in HeLa cells.
\end{abstract}

Keywords: lipid droplets, lipid metabolism, cell density, HeLa cervical cancer cells, unsaturated fatty acids, apoptosis

\section{Introduction}

Tumours have developed different molecular mechanisms that enable their uncontrolled proliferation. ${ }^{1}$ Oncogene activation and loss of tumour suppressors lead to both proliferative and metabolic reprogramming of cancer cells. The most common metabolic adaptations in cancer are increased glucose uptake, high rate of anaerobic glycolysis and increased glutamine consumption, but recent studies have revealed a dependence on elevated de novo lipid synthesis, internalization of exogenous lipids, mitochondrial fatty acid (FA) oxidation and lipid mediator-induced proliferative signalling. ${ }^{1-4}$ Lipids and their metabolites are currently under intense investigation in cancer-related studies, where new aspects of their role in cancer signalling, survival and apoptosis are beginning to emerge.

Lipid droplets (LDs) are now widely recognized as dynamic cytosolic organelles, present in all eukaryotic cells, with prominent roles reaching beyond that of inert energy storage depots. ${ }^{5}$ LDs are composed of a tightly packed core of neutral lipids, triacylglycerol (TAG) and sterol esters, surrounded by a phospholipid monolayer embedded with proteins and enzymes. At the cellular level, besides providing energy and building blocks for biosyntheses, they have important roles in protein quality control, viral replication and cell signalling, and are implicated in physiological processes ranging from immunity to neural development. ${ }^{6}$ Strong evidence suggests that LDs also control the synthesis of an array of lipid signal- 
ling molecules and that changes in LD metabolism influence the risk of developing metabolic diseases and cancer. $^{7,8}$

Increased accumulation of LDs has been observed in cancer cells in vivo and in vitro and LDs have been proposed as markers of cancer aggressiveness. ${ }^{2,4,9-12}$ The mechanisms of their involvement in cancer are currently under intense investigation. LDs are primary cellular sources of FAs for mitochondrial $\beta$-oxidation, which has been shown to enable cancer cell survival during various stress conditions. ${ }^{13-15}$ We have previously shown that secreted phospholipase $\mathrm{A}_{2}$-induced release of unsaturated FAs induces TAG synthesis and LD formation in aggressive breast cancer cells, thus stimulating proliferation and preventing cell death during serum starvation. ${ }^{16,17}$ The protective effects of LDs are associated with upregulation of $\beta$-oxidation enzymes and may be abolished with etomoxir, a potent inhibitor of $\beta$-oxidation. Intriguingly, LD formation is also induced during complete cell starvation, i.e. in the absence of glucose, amino acids and exogenous sources of lipid, when LDs become critical for providing FAs for $\beta$-oxidation that enables the survival of different cells, including HeLa cervical cancer cells. ${ }^{18,19}$

The role of different unsaturated FA species in supporting LD accumulation and cell survival in different cancer cell types in different environmental conditions is not clear. In general, LDs prevent FA lipotoxicity by acting as transient buffers for excess endogenous and exogenous FAs. Saturated FAs are particularly toxic to the cell and induce ER-stress and apoptosis, while monounsaturated FAs, such as oleic acid (OA; 18:1, $\omega-9)$, are generally regarded as cytoprotective. ${ }^{20}$ The supplementation of unsaturated FAs may even avert lipotoxicity by syphoning saturated FAs to inert TAGs stored in LDs. ${ }^{21}$ A number of studies have demonstrated that polyunsaturated FAs (PUFAs) have distinct and contrasting effects in cancer, with $\omega-6$ PUFAs, such as arachidonic acid (AA; 20:4, $\omega$ $6)$, mostly displaying pro-tumorigenic effects and $\omega-3$ PUFAs, such as eicosapentaenoic (EPA; 20:5, $\omega-3)$ and docosahexaenoic acid (DHA; 22:6, $\omega-3$ ), showing anti-tumorigenic, anti-inflammatory and pro-apoptotic effects in cancer cells. ${ }^{22,23}$ However, the association between LD metabolism and individual FA species in the context of cancer cell survival and metabolism is unknown. Here we studied the ability of different exogenous unsaturated FAs, namely OA, linoleic acid (LA; 18:2, $\omega-6$ ), AA, EPA and DHA to induce LD formation and affect cell death in HeLa cervical cancer cells.

\section{Experimental}

\section{1. Materials}

HeLa cervical adenocarcinoma cells (HeLa H2 clone) were obtained from John V. Moran, Howard Hughes Medical Institute, USA. MDA-MB-231 breast adenocar- cinoma cells and RPMI-1640 culture medium were from ATCC (USA). DMEM, foetal bovine serum (FBS) and Dulbecco's phosphate buffered saline (DPBS) were from Gibco, USA. Nile Red, tetramethylrhodamine, methyl ester (TMRM), LA, EPA, DHA, AA, fatty acid-free bovine serum albumin (FAF-BSA) were from Sigma-Aldrich (USA), YO-PRO-1 iodide, TrypLE Select were from Life Technologies (USA), while OA and DMSO were from Merck (Germany).

\section{2. Cell Lines and Culture Conditions}

HeLa and MDA-MB-231 cells were cultured in DMEM and RPMI-1640 medium, respectively, supplemented with $10 \%$ FBS. In experiments with serum-deprived cells, FBS was replaced by $0.02 \%$ FAF-BSA to render cells quiescent. Exogenously added FAs were complexed with $0.5 \%$ FAF-BSA or $10 \%$ FBS in culture medium for $1 \mathrm{~h}$ at room temperature before addition to cell culture.

\section{3. Flow Cytometry Analysis of Cellular LD Content}

LD analysis was performed as described previously. ${ }^{16}$ Briefly, cells were seeded in complete medium in 24-well culture plates, left to attach for $24 \mathrm{~h}$, and treated with different concentrations of FAs for $48 \mathrm{~h}$. Prior to treatment, FAs were complexed as described above. Cells were harvested, the pellet resuspended in $500 \mu \mathrm{l}$ of 1 $\mu \mathrm{g} / \mathrm{ml}$ Nile Red solution in DPBS, incubated in the dark for $10 \mathrm{~min}$ and analysed by flow cytometry on a BD FACSCalibur system (BD Biosciences, USA). Logarithmic fluorescence signals were collected using the FL1 filter $(530 / 30)$ from at least $2 \times 10^{4}$ events per sample.

\section{4. TMRM/YO-PRO-1 Apoptosis Assay}

Cell death was determined by measuring mitochondrial and plasma membrane integrity using the TMRM/YO-PRO-1 assay and flow cytometry as described prevoiously. ${ }^{17}$ Cells were seeded in complete medium in 24-well plates at a concentration of $3 \times 10^{4}$ cells/well. $24 \mathrm{~h}$ later, the medium was replaced by serum-free DMEM containing $0.02 \%$ FAF-BSA and the cells prestarved for $24 \mathrm{~h}$. Medium was replaced, cells treated with different concentrations of FAs (pre-complexed with DMEM containing 0.5\% FAF-BSA) and incubated for $168 \mathrm{~h}$. Cells were harvested, the pellet resuspended in 100 $\mu \mathrm{l}$ of $150 \mathrm{nM}$ TMRM in DPBS and incubated in the dark for $15 \mathrm{~min}$. Finally, $1 \mu \mathrm{l}$ of $20 \mu \mathrm{M}$ YO-PRO-1 in DMSO was added and cells incubated for additional $10 \mathrm{~min}$. TMRM and YO-PRO- 1 signals from $5 \times 10^{4}$ cells per sample were measured by flow cytometry using the FL1 (530/30) and FL3 (650LP) filters. TMRM negative and YO-PRO-1 positive cells were considered apoptotic. 


\section{5. Statistical Analysis}

Data are presented as means \pm SEM. Graphpad Prism (GraphPad Software, USA) was used for statistical analysis, using one-way ANOVA with Bonferroni adjustment for multiple comparisons. $\mathrm{P}$ values lower than 0.05 were considered statistically significant.

\section{Results and Discussion}

In the course of our flow cytometry assay optimization for the detection of LDs in HeLa cells, we observed significant changes in their LD content depending on the number of cells seeded. In order to determine whether cell density affects LD accumulation, HeLa cells were seeded at different densities, grown for $48 \mathrm{~h}$ in complete medium and the average LD amount in the cell population was determined by flow cytometry. We found that the LD content in HeLa cells increased proportionally with cell density (Fig. 1a). On the contrary, the average LD amount in MDA-MB231 breast cancer cells, a cell line with high propensity for LD formation from exogenous FAs, ${ }^{16}$ decreased with cell density (Fig. 1b). Namely, rapidly proliferating cancer cells grown in complete medium are highly metabolically active and they take up and metabolize glucose and amino acids to support biosynthesis, cell growth and proliferation. ${ }^{1}$ Lipids may be synthesized de novo or are taken up from exogenous sources, and are necessary for the maintenance and synthesis of cell membranes and thus a prerequisite for cell proliferation. ${ }^{4}$ Therefore, we expected that LD content will decrease with increasing cell density, since there is an increasing number of cells competing for the fixed supply of exogenous lipids found in serum. The increase in LD

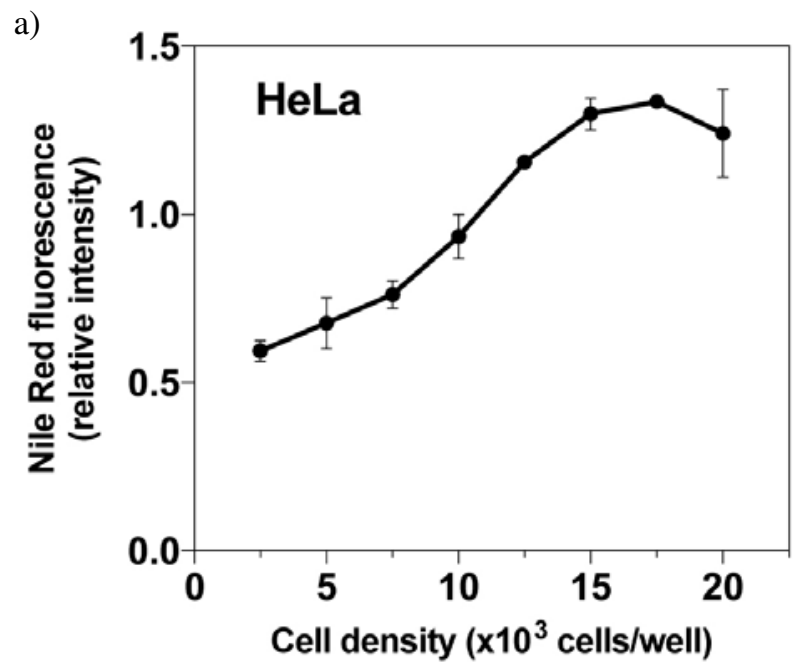

amount in HeLa cells suggests that with increasing cell density, and in the absence of contact inhibition, HeLa cells either gradually increase the rate of exogenous lipid uptake or significantly upregulate de novo lipid synthesis. In both cases, LDs may be necessary for supporting cell growth and proliferation processes characteristic of HeLa cells. In support of our finding, a similar relationship between LD amount and cell density has been reported for C6 rat glioma cells in culture, ${ }^{24}$ and, interestingly, an increase in the amount and size of LDs is characteristic of adipogenic differentiation, which may occur also in cancer cells, including cancer stem cell subpopulations of HeLa cells. ${ }^{25,26}$ Although the role of LDs in cell growth and proliferation is not clear, it may be easily envisaged that LDs act as master regulators of cellular lipid homeostasis, finely tuning the balance between lipid requirements and supply during cell growth. Additionally, LDs may be necessary to alleviate ER-stress that occurs in cancer cells undergoing oncogenedriven, uncontrolled proliferation. ${ }^{27,28}$

We next asked whether different exogenous unsaturated FA species vary in their abilities to induce LD accumulation in HeLa cells. We found that all tested FAs displayed a similar ability to modulate LD accumulation in HeLa cells (Fig. 2a-e). As expected, high micromolar concentrations of FAs, which are regularly used to induce LD formation in various cell types, stimulated LD accumulation in HeLa cells. This is in accordance with the conserved mechanism of prevention of FA lipotoxicity by their incorporation into TAG and LD formation ${ }^{20,21}$ Surprisingly, a slight decrease in neutral lipid levels was observed when cells were exposed to low concentrations of FAs (10 $\mu \mathrm{M}$ and below; Fig. 2a-e). A statistically significant reduction for LA, AA and DHA, which reduced LD amounts by 20,15 and $19 \%$, respectively, was indeed confirmed in a separate experiment using

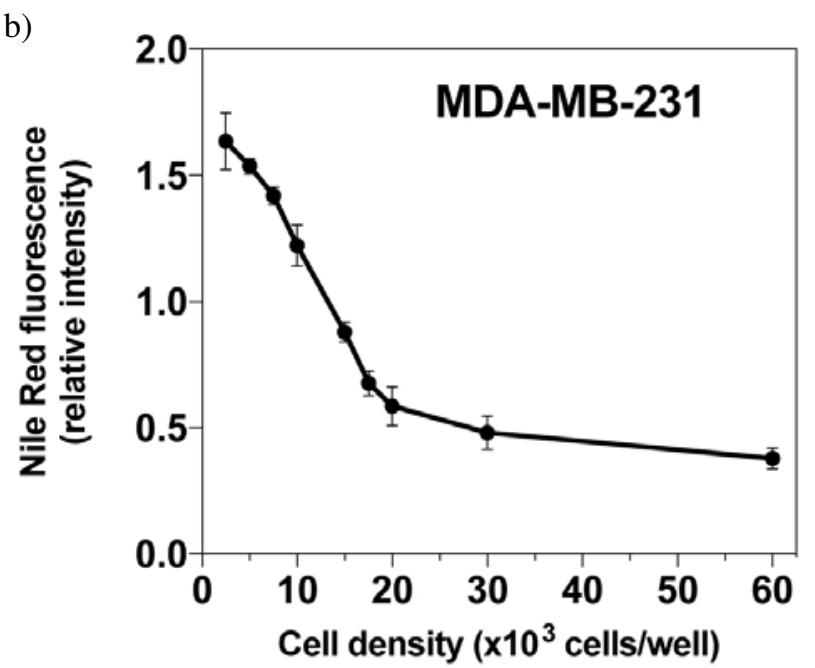

Figure 1. LD content in HeLa cells increases with cell density. (a) HeLa and (b) MDA-MB-231 cells were seeded in 24-well plates at the stated cell densities in complete medium. After $24 \mathrm{~h}$ the medium was replaced and cells were cultivated for another $48 \mathrm{~h}$ in complete medium. Cells were collected, stained with Nile Red and LD content was determined by flow cytometry. The resulting values are means \pm SEM of at least two experiments performed in duplicate. 
a)

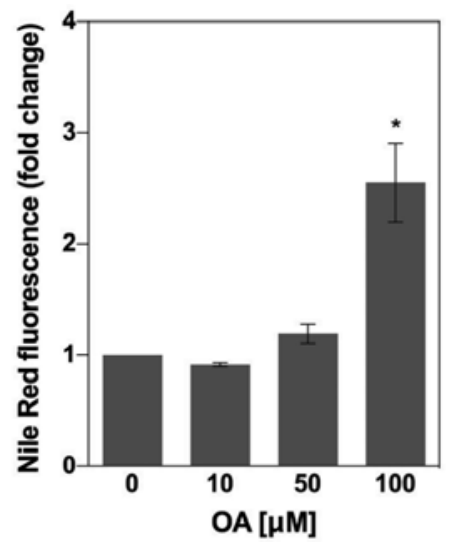

d)

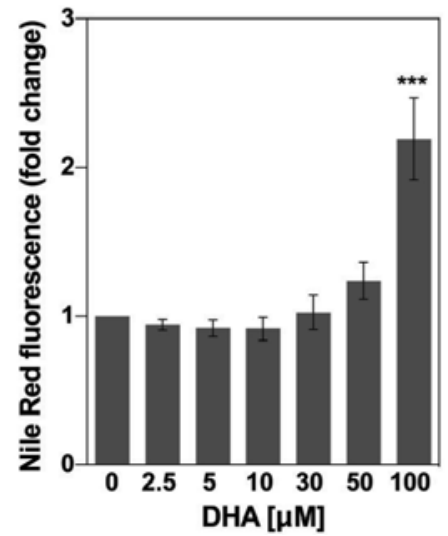

b)

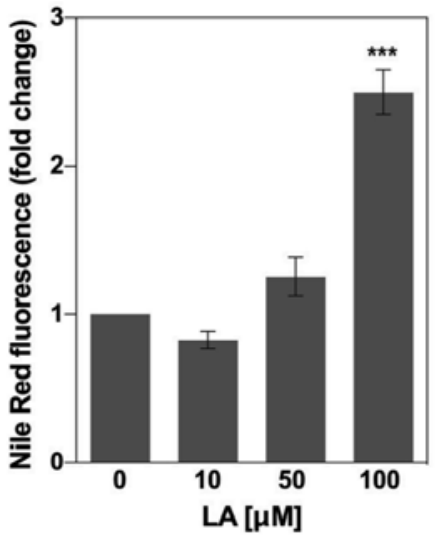

e)

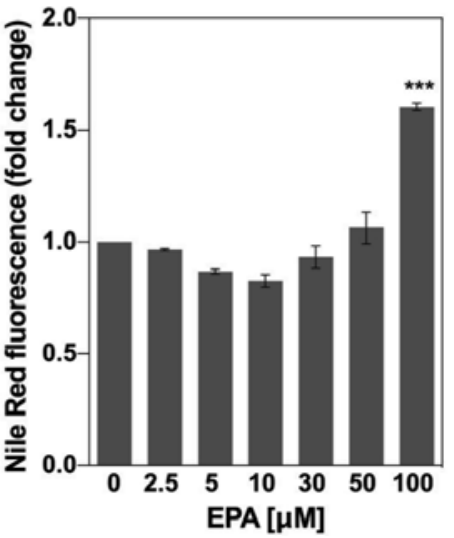

c)

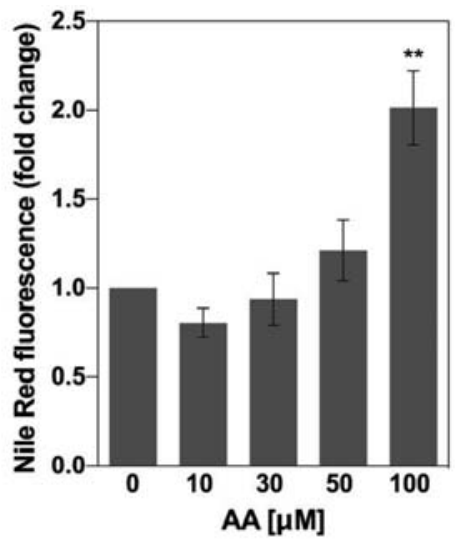

f)

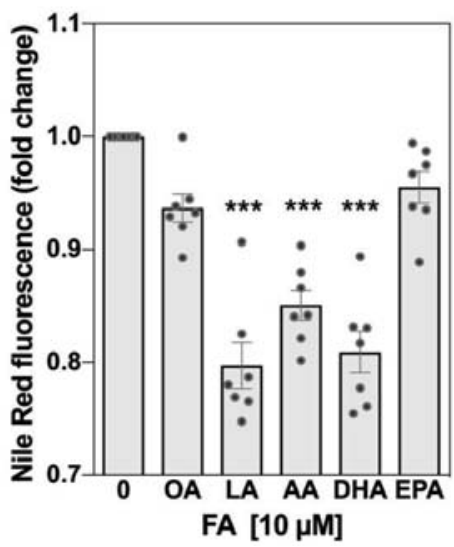

Figure 2. Unsaturated FAs have dual effects on LD accumulation in HeLa cells. (a) HeLa cells were grown for $48 \mathrm{~h}$ in complete media in the presence of a range of concentrations of OA (a), LA (b), AA (c), DHA (d) and EPA (e) or in the presence of $10 \mu \mathrm{M}$ of each FA (f). LD content was determined by flow cytometry. The resulting values are means \pm SEM of at least two (Fig. 2a-e) or seven (Fig. 2f) experiments performed in duplicate. Results that are statistically significant over control samples are indicated $(*, \mathrm{P}<0.05$; **, $\mathrm{P}<0.01$; ***, $\mathrm{P}<0.001$; one-way ANOVA with Bonferroni adjustment).

only $10 \mu \mathrm{M}$ FAs (Fig. 2f). The negative effect on LD accumulation may be a consequence of stimulated LD breakdown or suppressed LD formation, and is reminiscent to the anti-adipogenic effect of unsaturated FAs, in particular $\omega$-3 PUFAs, in differentiating adipocytes. ${ }^{29}$ The relevance of this finding for cancer cell biology remains to be established.

We have shown recently that OA induces LD formation in MDA-MB-231, MCF-7 and T-47D breast cancer cells, but it suppresses starvation-induced cell death only in MDA-MB-231 cells. ${ }^{16}$ To find out whether OA promotes LD accumulation and suppresses the death of HeLa cells, we treated starving HeLa cells with a range of concentrations of OA. Interestingly, we observed that OA induced significant LD accumulation only at the highest concentration used and it did not reduce, but it rather promoted cell death at higher concentrations (Fig. 3). Thus, in contrast to the highly invasive MDA-MB-231 cells, ${ }^{16}$ and despite the well-known cytoprotective effect of $\mathrm{OA},{ }^{20}$ our results suggest that serum-deprived HeLa cells cannot use exogenous OA to support cell survival. It is possible that starved HeLa cells are either not efficient in packa- ging exogenous OA into TAGs for transient storage in LDs or their LD breakdown pathways are overly active, thus leading to lipotoxicity of the unesterified OA.,31

\section{Conclusions}

We show that LD content in HeLa cells is proportional with cell culture density, that unsaturated FAs have differential effects on LD accumulation, and that OA cannot support the survival of starved HeLa cells. These interesting novel features of LD metabolism in HeLa cells may be useful for future studies providing fresh insights into cancer LD metabolism, in particular the relationship between cancer cell proliferation and lipid metabolism.

\section{Acknowledgements}

We are grateful to John V. Moran for providing the HeLa cell line. This work was supported by the 1000-15- 
a)

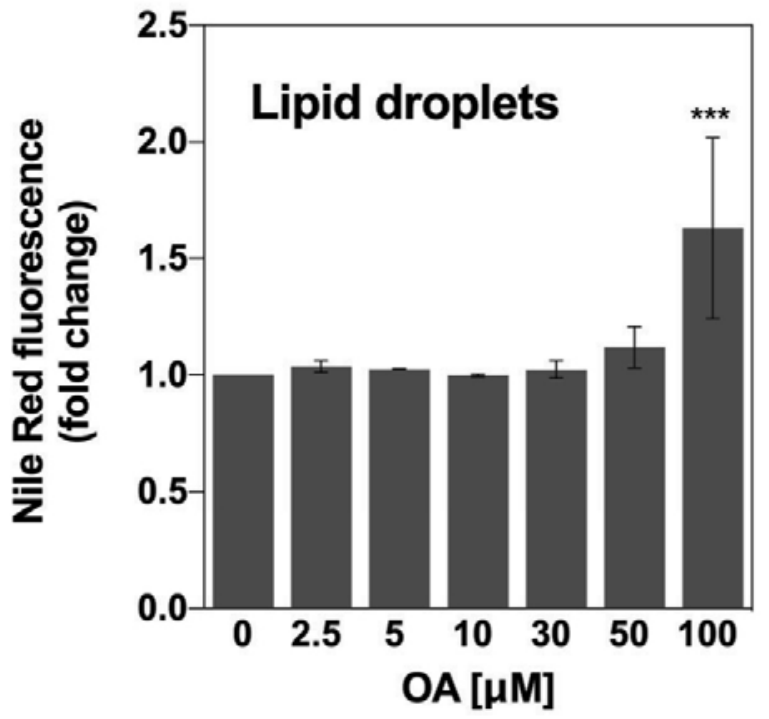

b)

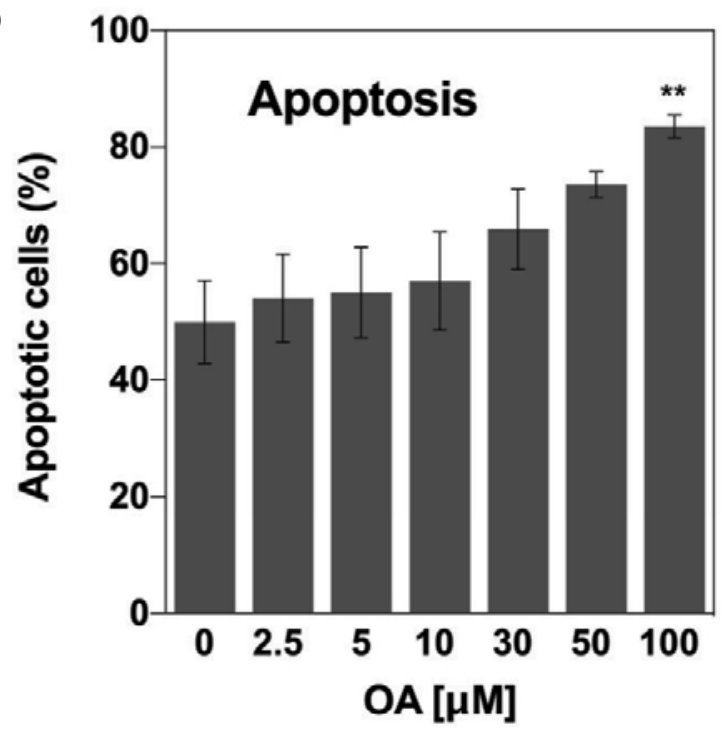

Figure 3. OA-induced LD accumulation does not provide a survival advantage for serum-deprived HeLa cells. HeLa cells were seeded in complete medium, left to attach for $24 \mathrm{~h}$ and pre-starved for $24 \mathrm{~h}$ in serum-deprived medium. Cells were then incubated with different concentrations of FAs for $168 \mathrm{~h}$ in serum-deprived medium. (a) LD content and (b) apoptosis were determined by flow cytometry. The resulting values are means \pm SEM of at least two experiments performed in duplicate. Results that are statistically significant over control samples are indicated (*, P $<0.05 ; * *, \mathrm{P}<0.01 ; * * *, \mathrm{P}<0.001$; one-way ANOVA with Bonferroni adjustment).

106 Young Researcher grant to E.J. and the P1-0207 Research Programme grant from the Slovenian Research Agency.

\section{Conflicts of interest}

None of the authors declare any conflict of interest.

\section{References}

1. N. N. Pavlova, C. B. Thompson, Cell Metab. 2016, 23, 2747. https://doi.org/10.1016/j.cmet.2015.12.006

2. S. Beloribi-Djefaflia, S. Vasseur, F. Guillaumond, Oncogenesis 2016, 5, 189. https://doi.org/10.1038/oncsis.2015.49

3. E. Currie, A. Schulze, R. Zechner, T. C. Walther, R. V. Jr. Farese, Cell Metab. 2013, 18, 153-61. https://doi.org/10.1016/j.cmet.2013.05.017

4. C. R. Santos, A. Schulze, FEBS J. 2012, 279, 2610-23. https://doi.org/10.1111/j.1742-4658.2012.08644.x

5. R. V. Farese, T. C. Walther, Cell 2009, 139, 855-60. https://doi.org/10.1016/j.cell.2009.11.005

6. Y. Ohsaki, M. Suzuki, T. Fujimoto, Chem. Biol. 2014, 21, 86-96.

https://doi.org/10.1016/j.chembiol.2013.08.009

7. A. Dichlberger, S. Schlager, K. Maaninka, W. J. Schneider, P. T. Kovanen, J. Lipid Res. 2014, 55, 2471-8. https://doi.org/10.1194/jlr.M048553

8. G. Haemmerle, T. Moustafa, G. Woelkart et al., Nat. Med. 2011, 1076-85. https://doi.org/10.1038/nm.2439

9. A. S. Greenberg, R. A. Coleman, F. B. Kraemer et al., J. Clin. Invest. 2011, 121, 2102-10.
https://doi.org/10.1172/JCI46069

10. L. Tirinato, C. Liberale, S. F. Di et al., Stem Cells 2015, 33, 35-44. https://doi.org/10.1002/stem.1837

11. T. M. Accioly, P. Pacheco, C. M. Monteiro-Maya et al., Cancer Res. 2008, 68, 1732-40.

https://doi.org/10.1158/0008-5472.CAN-07-1999

12. P. T. Bozza, J. P. Viola, Prostaglandins Leukot. Essent. Fatty Acids 2010, 82, 243-50.

https://doi.org/10.1016/j.plefa.2010.02.005

13. S. M. Jeon, N. S. Chandel, N. Hay, Nature 2012, 485, 661-5. https://doi.org/10.1038/nature11066

14. L. S. Pike, A. L. Smift, N. J. Croteau, D. A. Ferrick, M. Wu, Biochim. Biophys. Acta 2011, 1807, 726-34.

15. A. Carracedo, L. C. Cantley, P. P. Pandolfi, Nat. Rev. Cancer 2013, 13, 227-32. https://doi.org/10.1038/nrc3483

16. A. Pucer, V. Brglez, C. Payré, J. Pungerčar, G. Lambeau, T. Petan, Mol. Cancer 2013, 12, 111. https://doi.org/10.1186/1476-4598-12-111

17. V. Brglez, G. Lambeau, T. Petan, Biochimie 2014, Pt A: $114-23$.

18. A. S. Rambold, S. Cohen, J. Lippincott-Schwartz, Dev. Cell 2015, 32, 678-92. https://doi.org/10.1016/j.devcel.2015.01.029

19. A. G. Cabodevilla, L. Caballero-Sánchez, E. Nintou et al., J. Biol. Chem. 2013, 288, 27777-88. https://doi.org/10.1074/jbc.M113.466656

20. C. J. Nolan, C. Z. Larter, J. Gastroenterol. Hepatol. 2009, 24, 703-6. https://doi.org/10.1111/j.1440-1746.2009.05823.x

21. L. L. Listenberger, X. Han, S. E. Lewis et al., Proc. Natl. Acad. Sci. U. S. A. 2003, 100, 3077-82.

https://doi.org/10.1073/pnas.0630588100 
22. D. D'Eliseo, F. Velotti, J. Clin. Med. 2016, 5, 15. https://doi.org/10.3390/jcm5020015

23. B. Chénais, V. Blanckaert, Int. J. Breast Cancer 2012, 2012, 712536.

24. I. Barba, M. E. Cabañas, C. Arús, Cancer Res. 1999, 59, 1861-8.

25. J. Trullols-Carcel, C. Gallardo-Aguilar, F. Alcalde-Garcia et al., Springerplus 2012, 1, 44. https://doi.org/10.1186/2193-1801-1-44

26. L. Wang, H. Guo, C. Lin, L. Yang, X. Wang, Mol. Med. Rep. 2014, 9, 2117-23.
27. I. Hapala, E. Marza, T. Ferreira, Biol. Cell 2011, 103, 271-85. https://doi.org/10.1042/BC20100144

28. R. M. Young, D. Ackerman, Z. L. Quinn et al., Genes Dev. 2013, 27, 115-31.

29. H. K. Kim, M. Fera-Della, J. Lin, C. A. Baile, J. Nutr. 2006, 136, 2965-9.

30. E. Przybytkowski, E. Joly, C. J. Nolan et al., Biochem. Cell Biol. 2007, 85, 301-10. https://doi.org/10.1139/O07-001

31. M. Bosma, D. H. Dapito et al., Biochim. Biophys. Acta 2014, $1841,1648-55$.

\section{Povzetek}

Citosolne lipidne kapljice shranjujejo presežne maščobne kisline (MK) v obliki nevtralnih lipidov in preprečujejo smrt rakavih celic tekom stradanja. V tem delu smo preučili vplive mono- in polinenasičenih MK na tvorbo lipidnih kapljic in preživetje celic raka materničnega vratu HeLa. Pokazali smo, da vsebnost lipidnih kapljic v celicah HeLa narašča z gostoto celične kulture, v celicah raka dojke MDA-MB-231 pa pada. Eksogeno dodane nenasičene MK, oleinska (OK), linolna (LK), arahidonska (AK), eikozapentaenojska (EPK) in dokozaheksaenojska kislina (DHK) so imele podobne vplive na tvorbo lipidnih kapljic v celicah HeLa. Opazili smo dvojni, od koncentracije odvisen učinek na kopičenje nevtralnih lipidov: nizke mikromolarne koncentracije LK, AK in DHK so znižale količino lipidnih kapljic, medtem ko so pri višjih mikromolarnih koncentracijah vse MK inducirale njihovo tvorbo. OK je spodbudila tvorbo lipidnih kapljic v stradanih celicah HeLa, a je, nasprotno od pričakovanj, spodbudila tudi celično smrt. Naši rezultati razkrivajo povezavo med gostoto celic v populaciji in tvorbo lipidnih kapljic pri celicah HeLa in kažejo, da lahko nenasičene MK tako zavirajo kot tudi stimulirajo tvorbo lipidnih kapljic. To dinamično regulacijo vsebnosti lipidnih kapljic je potrebno upoštevati pri študijah učinkov lipidov in učinkovin, ki ciljajo lipidni metabolizem, na metabolizem lipidnih kapljic v celicah HeLa. 